\title{
EVALUASI KETERLAKSANAAN KURIKULUM 2013 PADA SEKOLAH MENENGAH ATAS DI KOTA MATARAM
}

\section{EVALUATION OF THE IMPLEMENTATION OF CURRICULUM 2013 AT SENIOR SECONDARY SCHOOLS IN MATARAM CITY}

\author{
Rahmatullah \& Jumadi \\ Pendidikan Fisika Pascasarjana Universitas Negeri Yogyakarta \\ Jl. Colombo No. 1 Yogyakarta \\ E-mail: rahmatullah.2019@student.uny.ac.id dan jumadi@uny.ac.id
}

Naskah diterima tanggal: 12-08-2020, disetujui tanggal: 21-09-2020

\begin{abstract}
This qualitative descriptive research aims to determine the implementation of Curriculum 2013 (K-2013) by assessing its context, input, process, and products. Assessment of context based on analysis of the objectives, benefits, and goals of K-2013. The input assessment is obtained from observations of school readiness, conditions of infrastructure, etcetera. The Process assessment is obtained from analysis of implementation in the field. The product assessment is obtained from the analysis of the output produced by $K-2013$. This study also analysed the obstacles, weaknesses and strengths of the Curriculum 2013. The research subjects were students, educators, vice principals in charged for the curriculum, and school principals. Methods of collecting information using observation, interviews, and document analysis. The research stage includes three processes, namely, the pre-survey, analysing the results of the observations, and writing the articles. The results of the observations are then analysed descriptively qualitatively. The results of the analysis found that besides providing benefits, the implementation of K-2013 had also some obstacles or shortcomings in its implementation. The obstacles are in the aspects of school policy, facilities and infrastructure, the learning process, and administration. In conclusion, the implementation of $\mathrm{K}-2013$ at the SMA level in the City of Mataram has been going well. However, it needs some adjustments to be made in its refinement, such as adjustments to the facilities support and the implementation process of $K-2013$.
\end{abstract}

Keywords: curriculum evaluation, Curriculum 2013, senior secondary schools, Mataram City

Abstrak: Penelitian ini merupakan penelitian desktiptif kualitatif dengan tujuan menilai konteks, input, proses dan produk pada kurikulum 2013 (K-2013). Penilaian konteks berdasarkan analisis tujuan, manfaat, dan sasaran $K$-2013. Penilaian input diperoleh dari pengamatan kesiapan sekolah, kondisi sarana prasarana, dan sebagainya. Penilaian proses diperoleh dari analisis terhadap pelaksanaan di lapangan. Penilaian produk diperoleh dari analisis output yang dihasilkan $K$-2013. Penelitian ini juga menganalisis hambatan, kekurangan dan kelebihan dari kurikulum 2013. Subjek penelitian yang digunakan yaitu peserta didik, pendidik, wakil kepala sekolah bidang kurikulum serta kepala sekolah. Metode pengumpulan informasi menggunakan observasi, wawancara dan analisis dokumen. Tahap penelitian meliputi tiga proses yaitu tahap prasurvei, tahap analisis hasil pengamatan, dan penulisan artikel. Hasil pengamatan yang telah didapatkan selanjutnya dianalisis secara deskriptif kualitatif. Hasil analisis menemukan bahwa penerapan $K-2013$ selain menghadirkan manfaat juga masih ada beberapa kendala atau kekurangan yang dirasakan dalam penerapannya sampai sejauh ini. Kendala yang muncul terdapat pada aspek kebijakan sekolah, sarana dan prasarana, proses pembelajaran, serta administrasi. Kesimpulan, 
keterlaksanaan K-2013 pada tingkat SMA di Kota Mataram berjalan dengan baik, tetapi perlu ada beberapa penyesuaian dalam penyempurnaan. Penyesuaian yang dapat dilakukan lebih kepada fasilitas penunjang dan proses pelaksanaan K-2013.

Kata kunci: evaluasi kurikulum, Kurikulum 2013, SMA, Kota Mataram

\section{PENDAHULUAN}

Pendidikan merupakan bagian dari aset pembangunan suatu bangsa. Pentingnya pendidikan bagi suatu bangsa yaitu dapat mengembangkan potensi sumber daya manusia (SDM). Pasal 5 ayat (1) Undang-undang Nomor 20 Tahun 2003 tentang Sistem Pendidikan Nasional menjamin hak setiap warga negara untuk mendapatkan pendidikan yang bermutu. Banyak pakar pendidikan yang memiliki pendapat berbeda mengenai pemahaman pendidikan yang bermutu namun pada dasarnya memiliki tujuan yang sama dalam pemberian layanan pendidikan bermutu kepada peserta didik (Yuliana, 2019). Perbaikan mutu pendidikan telah banyak dilakukan oleh pemerintah, walaupun keluhan seputar dunia pendidikan masih saja terjadi. Salah satu upaya yang dilakukan pemerintah adalah dengan melakukan pergantian pada kurikulum.

Kurikulum adalah jantung sebuah sekolah. Setiap sekolah berusaha membuat atau menyusun kurikulum sehingga dapat mengakomodasi tujuan dan kebutuhan (Agustin \& Puro, 2016). Menurut Nugraheni (2015), kurikulum adalah seperangkat rencana dan pengaturan mengenai tujuan, konten, dan materi pembelajaran dan cara menggunakannya sebagai panduan kegiatan belajar untuk mencapai tujuan pendidikan tertentu. Kurikulum bersifat dinamis, artinya kurikulum tersebut dapat berubah kapan saja berdasarkan keadaan atau faktor-faktor lain yang memengaruhinya. Kurikulum dapat berubah jika tekanan dalam tujuan mengalami pergeseran. Selain itu juga pendirian dalam proses belajar dan perubahan dalam masyarakat menjadi penyebab lain berubahnya suatu kurikulum. Oleh karena itu, perubahan kurikulum merupakan hal yang biasa.
Justru akan menjadi merugikan jika kurikulum tersebut masih dipertahankan.

Perubahan kurikulum sebagian besar disambut baik oleh para pendidik, sarjana pendidikan, dan masyarakat umum. Namun, perubahan itu tidak lepas dari kritik. Kritik sebagian besar tertuju pada implementasi perubahan. Penelitian yang dilakukan sejauh ini menunjukkan bahwa kurangnya dukungan materi dan peluang pelatihan bagi para pendidik, sumber dan bahan yang langka, infrastruktur teknologi dan fasilitas fisik yang buruk adalah kendala utama sebelum pencapaian tujuan yang dijabarkan dalam reformasi (Ozturk, 2011).

Perubahan Kurikulum Tingkat Satuan Pendidikan (KTSP) menjadi Kurikulum 2013 tentu berdasarkan maksud dan tujuan yang baik. Perubahan kurikulum ini dilakukan untuk menjawab tantangan zaman yang terus berubah agar peserta didik dapat bersaing di masa depan. Menurut Ahmad (2014), perubahan kurikulum dilakukan agar sistem pendidikan yang ada bersesuaian dengan perkembangan peradaban seperti ilmu pengetahuan dan teknologi. Akibat dari kemajuan teknologi ini, pembelajaran yang mulanya tradisional berubah ke arah yang mutakhir (Hamalik, 2012).

KTSP dipandang kurang mampu dalam memenuhi kompetensi abad 21. Dalam proses pembelajaran abad 21 dengan perkembangan teknologi informasi yang meningkat pesat, dibutuhkan sebuah kurikulum yang adaptif dengan kondisi saat ini. Oleh karena itu, tahun 2013 pemerintah mengeluarkan Permendikbud Nomor 65 yang menghasilkan sebuah kurikulum yang dikenal sebagai Kurikulum 2013 (Kementerian Pendidikan dan Kebudayaan, 2013). 
K-2013 dianggap lebih adaptif dengan kondisi saat ini karena pembelajaran diwarnai empat komponen yakni: fakta, konsep, prinsip, prosedur serta ciri pembelajaran di era modern yakni STEM (science, technology, engineering dan mathematics). K-2013 berprinsip pada penekanan pembelajaran yang berorientasi pada sesuatu yang menantang, otentik, dan bermakna oleh pendidik sehinggga potensi peserta didik dapat berkembang sesuai harapan dan tujuan pendidikan (Kurniaman \& Noviana, 2017). Pendidik sejatinya adalah seorang fasilitator dalam pembelajaran di kelas. Selama pembelajaran berlangsung, aktivitas belajar seharusnya didominasi oleh peserta didik. Namun kenyataannya masih terdapat dibeberapa tempat yang memperlihatkan pendidik sebagai pusat pembelajaran.

Karakteristik pembelajaran pada K-2013 yaitu menjadikan masyarakat sebagai sumber belajar dengan mengaitkannya dalam kehidupan sehari-hari. Hasil yang didapatkan peserta didik nantinya dapat diterapkan dalam kehidupan sehari-hari. Pengetahuan didapatkan untuk pengembangan ilmu, sikap bermasyarakat yang baik, dan keterampilan untuk bertahan hidup.

Seiring dengan telah dilaksanakannya K2013, pro dan kontra masih banyak ditemui. Pada awal diberlakukan K-2013-pun sudah menjadi perbincangan yang hangat. Banyak kalangan akademisi yang mempertanyakan kehadiran K-2013. Penelitian Ahmad (2014) menyatakan bahwa pendidikan karakter yang dimunculkan pada K-2013 sulit untuk diterapkan. Selain sulit mendapatkan figur teladan, pengembangan karakter juga sulit untuk diterapkan kecuali ada asrama untuk setiap sekolah. Retnaningsih (2012) juga menjelaskan bahwa kendala utama yang terjadi ketika implementasi K-2013 adalah keterbatasan fasilitas teknologi, informasi, dan komunikasi (TIK). Hasil observasi lapangan juga memperlihatkan bahwa masih ada sekolah yang sampai saat ini terkendala fasilitas TIK untuk menunjang pembelajaran. Kompetensi pendidik dalam menguasai teknologi juga menjadi kendala ketika K-2013 dicoba untuk diterapkan. Pengintegrasian TIK ke dalam pembelajaran sejauh ini terbatas dilakukan sebagian kecil pendidik saja (Rivalina, 2014).

Hingga saat ini, penerapan K-2013 di Indonesia sudah berjalan selama tujuh tahun. Lambat laun, kurikulum tersebut dapat diterima oleh masyarakat dunia pendidikan dan juga masyarakat luas umumnya. Namun demikian, masih ada beberapa catatan dari pendidik dan peserta didik di sekolah yang menjadi bahan evaluasi terhadap pelaksanaan K-2013 ini. Nusa Tenggara Barat (NTB) yang menjadi salah satu provinsi pelaksana K-2013 menjadi perhatian khusus. Sebab Berdasarkan hasil Penilaian Ujian Nasional tingkat SMA memposisikan NTB sebagai peringkat 33 dari 34 provinsi (Zamhuri, 2019). Hasil ini mempertanyakan implementasi Kurikulum 2013 yang sudah diterapkan sejauh ini.

Kota Mataram yang menjadi ibu kota provinsi belum bisa berbicara banyak terhadap hasil pendidikan di NTB. Tabel 1 menunjukkan bahwa masih banyak peserta didik yang memiliki

Tabel 1 Perolehan Nilai Ujian Nasional Kota Mataram

\begin{tabular}{ccccc}
\hline \multirow{2}{*}{ No. } & Rentang nilai & Kategori & \multicolumn{2}{c}{ Nilai Ujian Nasional } \\
& & & 2018 & 2019 \\
\hline 1 & $>85-100$ & Baik Sekali & 32 & 47 \\
2 & $>70-\leq 85$ & Baik & 399 & 419 \\
3 & $>55-\leq 70$ & Cukup & 1159 & 1234 \\
4 & $0-\leq 55$ & Kurang & 2469 & 2226 \\
\hline
\end{tabular}


rentang nilai pada kategori kurang (Kemdikbud, 2019). Hasil nilai ujian menjadi bagian dari tolak ukur pengaruh kurikulum bagi kemajuan pendidikan suatu daerah. indikator dari baiknya kualitas pendidikan yaitu terletak pada kompetensi lulusan atau kemampuan yang dimiliki Iulusan (Mardapi, 2005).

Berdasarkan latar belakang dan kajian literatur di atas, perlu dilakukan sebuah evaluasi keterlaksanaan kurikulum mengingat perkembangan zaman yang begitu cepat sehingga memicu beberapa kendala lapangan. Evaluasi yang dilakukan merupakan bentuk penilaian dan perbaikan untuk mendapatkan kurikulum yang tepat sesuai kondisi dan kebutuhan yang ada sehingga kualitas pendidikan terus meningkat. Oleh sebab itu, rumusan permasalahan penelitian ini yaitu 1) bagaimana proses pelaksanaan kurikulum 2013 sejauh ini? 2) apa saja kekurangan dan kelebihan yang terdapat pada kurikulum 2013?

Tujuan dari penelitian ini yaitu untuk menilai konteks, input, proses dan produk dari Kurikulum 2013. Selain itu, penelitian ini juga mencakup pengamatan pada hambatan, kekurangan dan kelebihan K-2013 berdasarkan implementasi di sekolah. Manfaat yang dapat diambil dari penelitian ini adalah sebagai bentuk perbaikan kurikulum agar menjadi lebih baik lagi seiring dengan perkembangan zaman.

\section{METODE}

Penelitian ini merupakan penelitian desktiptif kualitatif. Penelitian deskriptif yaitu penelitian yang bertujuan untuk mendeskripsikan atau menjelaskan suatu peristiwa, objek, atau keadaaan terkait dengan beberapa variabel yang dapat dijelaskan dengan kata-kata maupun angka (Setyosari, 2010). Penelitian kualitatif berusaha memahami sebuah fenomena dengan berfokus pada gambaran keseluruhan melalui observasi dan wawancara mendalam (Ary, Jacobs, \& Sorensen, 2010).
Penelitian deskriptif kualitatif yang dimaksud adalah dengan mengumpulkan data atau informasi yang bersifat deskriptif dengan membatasinya berdasarkan beberapa indikator untuk mengoreksi kebenaran data. Hasilnya disepakati oleh dua belah pihak baik itu subjek penelitian maupun peneliti dan rancangan penelitian yang bersifat sementara (Mastur, 2017).

Penelitian ini dilakukan pada tanggal 9 Desember 2019. Subjek penelitian ini adalah kepala sekolah, wakil kepala sekolah bidang kurikulum, serta pendidik dan peserta didik yang ada di beberapa sekolah menengah atas (SMA) di Kota Mataram. Pendekatan penelitian berdasarkan pada beberapa pertimbangan di antaranya implementasi pada tatanan sekolah dan pada tingkat kelas (pelaksanaan pembelajaran). Pelaksanaan pembelajaran yang menjadi objek kajian adalah kegiatan perencanaan, pelaksanaan, dan hasil belajar dalam bentuk prestasi yang didapatkan.

Model evaluasi yang digunakan yaitu model CIPP (context, input, process and product). Tahap yang dilakukan dalam penelitian ini meliputi tiga hal yaitu tahap prasurvei, survey, dan analisis hasil pengamatan, serta penulisan artikel.

Pada tahap prasurvei, peneliti terlebih dahulu menyiapkan alat dan bahan penelitian di antaranya lembar observasi dan wawancara. Metode observasi dilakukan bertujuan untuk pengamatan secara luas guna mendapatkan informasi yang umum seputar sekolah.

Lembar observasi yang dibuat ditujukan pada subjek penelitian untuk mengetahui kesiapan dan hasil yang didapat dalam menerapkan K-2013 selama ini. Lembar observasi dilengkapi dengan pedoman observasi yang tepat. Sebagai pelengkap hasil observasi, peneliti juga menggunakan metode wawancara. Pertanyaan wawancara yang dibuat berisi selayaknya lembar observasi. Namun, terdapat beberapa pertanyaan pengembangan atas apa 
yang ditemukan dari hasil observasi yang semu. Selain dengan menggunakan lembar observasi, analisis dokumentasi, dan studi literatur juga diperlukan untuk memperkuat temuan-temuan yang ada.

Tahap selanjutnya adalah tahap survei dan analisis data. Observasi yang dilakukan pada tahap survei bersifat pasif artinya peneliti hanya mengamati tanpa ikut terlibat langsung dalam kegiatan yang diamati. Sementara itu, wawancara yang dilakukan bersifat sepihak, artinya peneliti yang aktif bertanya sementara pihak yang ditanya aktif memberikan jawaban atau tanggapan. Setelah data hasil observasi dan wawancara didapatkan, peneliti menganalisis sehingga dapat mengevaluasi dan menjawab permasalahan yang ada. Sampai pada akhirnya temuan-temuan yang didapatkan ditulis dalam artikel ini.

\section{HASIL DAN PEMBAHASAN}

Berdasarkan hasil observasi, wawancara, dan studi literatur yang ada, terdapat beberapa bahan evaluasi yang menjadi fokus penelitian pada K-2013. Evaluasi yang dilakukan berupa evaluasi konteks, input, proses, dan produk. Evaluasi konteks mambahas tentang visi dan misi sekolah, tujuan program yang disusun sekolah, dan prediksi kebutuhan ke depan. Evaluasi input yang dibahas meliputi kesiapan tenaga pendidik, sarana dan prasarana, sosialisasi pelaksanaan kurikulum, dan bukubuku. Evaluasi proses meliputi indikator pembuatan RPP dan silabus, pembuatan metode dan media pembelajaran, pelaksanaan pembelajaran dan penilaian. Evaluasi produk membahas mengenai produk silabus dan RPP yang dihasilkan pendidik, serta prestasi akademik dan nonakademik yang dihasilkan. Berikut akan dibahas tiap-tiap evaluasi yang telah dilakukan.

\section{Evaluasi Konteks Kurikulum 2013}

Evaluasi konteks diperoleh dari menganalisis tujuan, manfaat, dan sasaran implementasi K2013. Berdasarkan hasil pengamatan di Kota Mataram bahwa pelaksanaan K-2013 telah berjalan dengan baik. Namun, di sisi lain masih ada beberapa kekurangan yang perlu dibenahi berdasarkan konteks yang diharapkan.

Dari segi tujuan, K-2013 telah memberikan harapan bagus bagi dunia pendidikan, salah satunya berdampak signifikan bagi perkembangan budi pekerti peserta didik di Kota Mataram. Sejauh ini perkelahian pelajar antarsekolah maupun satu sekolah di Kota Mataram sudah jarang terjadi jika dibandingkan dengan ketika menggunakan kurikulum sebelumnya. Beberapa sekolah telah melakukan berbagai program yang baik di antaranya sekolah ramah anak, piket karakter (salaman dengan peserta didik di depan sekolah) dan lain sebagainya. Usaha penerapan pendidikan karakter di sekolah membuahkan hasil yang cukup baik, meskipun ada sedikit pelanggaran yang terjadi di lapangan oleh pelaksana kurikulum.

Berbeda hasilnya jika dibandingkan dengan data nasional dari KPAI. Komisi Perlindungan Anak Indonesia (KPAI) mengungkapkan bahwa kekerasan dalam dunia pendidikan masih tinggi (Setyawan, 2017). KPAI mencatat ada 84\% peserta didik di Indonesia mengalami bahkan melakukan kekerasan. Kekerasan ini dilakukan oleh pendidik terhadap peserta didik, peserta didik terhadap pendidik, atau sesama peserta didik.

Kekerasan yang terjadi di dunia pendidikan dapat disebabkan oleh kebijakan yang ada. Kebijakan yang dikeluarkan oleh pemerintah dalam bentuk Undang-undang Perlindungan sangatlah tepat. Undang-undang No. 35 Tahun 2014 tentang Perlindungan Anak mengamanatkan bahwa sekolah seharusnya menjadi tempat yang nyaman dan aman bagi peserta didik. Namun demikian, sekolah yang merasa mengerti kondisi dan keadaan di lapangan terkadang memilih opsi lain dalam menerapkan 
kebijakan yang lain. Sebagai contoh, kebijakan dari sekolah yang dialami oleh peserta didik ketika mereka melakukan pelanggaran kode etik di sekolah. Mereka terkadang mendapatkan hukuman fisik bahkan hukuman sosial yang tidak terkesan mendidik. Hukuman fisik yang biasa terjadi adalah berlari mengelilingi lapangan. Dampak dari hal ini adalah kerusakan mental yang ada dalam diri peserta didik yang dapat mengurangi motivasi untuk belajar. Hukuman fisik bukannya memberikan perbaikan pada perilaku peserta didik, justru menjadikan mereka semakin anti sosial (Sara, 2011). Menurut Nur'aeni (2017) penyebab kekerasan dipengaruhi oleh kondisi lingkungan yang buruk dan tingkat kriminalitas yang tinggi.

Hukuman yang didapatkan peserta didik terkadang membuatnya menjadi antipati dan melawan kebijakan yang ada. Pendidik yang seharusnya mereka hormati justru dimusuhi. Sehingga banyak juga kasus yang muncul ketika peserta didik melawan dan bahkan menantangnya untuk melakukan perkelahian fisik. Kejadian ini mengindikasikan bahwa harapan K2013 untuk menciptakan pribadi (akhlak) yang baik pada peserta didik masih belum sempurna.

Seyogyanya setiap elemen dalam dunia pendidikan memaknai apakah hakikat dari K-2013 sehingga dapat benar-benar diterapkan dengan baik. Pihak sekolah sendiri tentu telah membuat visi dan misi yang mengadopsi pada harapan dari K-2013. Usaha ini membutuhkan pengawasan yang tepat dari pihak pemerintah dalam hal ini dinas pendidikan terkait. Fungsi kontrol sangat membantu terealisasinya komponen-komponen K-2013 secara menyeluruh.

Pengawasan yang dilakukan dinas terkait memberikan peluang dalam memprediksi kebutuhan ke depan. Seiring dengan perkembangan zaman, kebutuhan juga akan berubah. Kurikulum dapat saja disempurnakan berdasarkan input yang ada di lapangan. Penyesuaian ini tentu akan berdampak positif dengan mereduksi pada apa yang menjadi tuntutan zaman.

\section{Evaluasi Input Kurikulum 2013}

Evaluasi input diperoleh dari pengamatan sejauh mana kesiapan sekolah, kondisi sarana prasarana, sosialisasi, dan buku-buku. Berdasarkan hasil wawancara dengan beberapa pendidik diketahui bahwa sekolah masih memiliki kendala dalam hal sarana dan prasarana untuk menerapkan K-2013. Beberapa komponen yang harus ada dalam menerapkan apa yang diinginkan oleh K-2013, salah satunya adalah penggunaan media dalam pembelajaran. Komputer menjadi salah satu sarana yang mampu mendukung keterlaksanaan K-2013. Mengacu pada penghapusan mata pelajaran TIK mengharuskan setiap mata pelajaran mereduksi pembelajaran berbasis teknologi, informasi, dan komunikasi. Terkait dengan hal ini, sekolah membutuhkan sarana dan prasarana untuk menunjang dan membantu menyukseskan implementasi K-2013. Namun, faktanya masih banyak sekolah-sekolah yang mengalami kekurangan dalam sarana dan prasarana. Pendidik menghadapi dilema ketika hendak mengaplikasikan pembelajaran berbasis media dengan komputer tetapi perangkat tersebut tidak memadai. Retnaningsih (2012) juga menjelaskan hal yang demikian.

Fasilitas komputer sebagai penunjang pelaksanaan K-2013 menjadi begitu sangat penting terlebih lagi ketika melakukan penilaian akhir UNBK di setiap tahunnya. Peserta didik yang tidak terbiasa dalam menggunakan komputer memiliki hasil yang berbeda dengan peserta didik yang terbiasa menggunakan komputer. Sebuah studi yang dilakukan oleh Yudhi (2019) menguji hasil UNBK peserta didik antara sekolah mandiri dalam pelaksanaan UNBK dan sekolah non-mandiri. Sekolah yang melaksanakan UNBK mandiri menunjukkan pencapaiaan UN yang lebih tinggi dibandingkan sekolah dengan UNBK non-mandiri dari tahun 
2017 hingga 2019. Artinya bahwa fasilitas yang memadai dari sekolah memiliki pengaruh signifikan terhadap hasil belajar peserta didiknya.

Sarana dan prasarana lain yang mampu mendukung keterlaksaan K-2013 adalah rasio luas halaman dengan jumlah peserta didik yang ada. Temuan yang didapatkan bahwa masih ada sekolah yang memiliki rasio yang tidak ideal. Mengingat pembelajaran K-2013 menggunakan model tematik dengan pendekatan saintifik maka peserta didik membutuhkan tempat untuk melakukan pengamatan (eksplorasi), misalnya di halaman sekolah. Hal ini menjadi bahan pertimbangan bagi sekolah dan pemerintah untuk menghadirkan solusi. Halaman sekolah tidak hanya dapat digunakan untuk satu kepentingan (mata pelajaran) saja melainkan juga untuk kepentingan kegiatan belajar bersama.

Solusi untuk menyikapi keterbatasan halaman yang dimiliki sekolah adalah dengan melakukan kegiatan pengamatan di dalam ruang kelas. Perangkat yang dapat digunakan adalah komputer. Misalnya pembelajaran fisika yang dapat menggunakan aplikasi Lab Virtual. Jadi, peserta didik dapat melakukan pengamatan tanpa harus keluar kelas. Menurut Gunawan, Harjono, Sahidu, \& Herayanti (2017) pembelajaran dengan menggunakan laboratorium virtual dapat berpengaruh positif terhadap kemampuan pemecahan masalah peserta didik. Hasil penelitian menunjukkan bahwa virtual lab efektif untuk meningkatkan konsep yang sulit dan keberhasilan diri dengan inkuiri ilmiah (Husnaini \& Chen, 2019).

Mengingat pentingnya K-2013 bagi sekolah dan peserta didik, perlu dilakukan sebuah kegiatan sosialisasi. Pemerintah telah melakukan tugasnya dengan baik untuk melaksanakan sosialisasi hingga simulasi pendampingan dalam pembelajaran. Sejauh ini semua sekolah yang ada di Kota Mataram telah menerapkan K-2013. Meskipun di beberapa sekolah daerah lain masih ada yang terlambat dalam memulai karena beberapa faktor penghambat. Alasan terlambat mendapatkan sosialisasi karena sarana dan prasarana yang kurang mendukung. Hal ini adalah salah satu sebab dari terhambatnya penerapan K-2013.

Kegiatan sosialisasi tidak hanya perlu diberikan kepada pihak sekolah atau pendidik. Peserta didik juga memerlukan sosialisasi tersebut. Sosialisasi dapat dilakukan oleh pendidik langsung kepada peserta didik. Berdasarkan hasil observasi diketahui bahwa peserta didik, banyak yang masih belum paham tentang hakikat K-2013. Mereka hanya mengikuti apa yang menjadi arahan di dalam kelas. Ketika dihadapkan dengan pendekatan saintifik yang menuntut pembelajaran student-centered, peserta didik merasa diberatkan. Padahal, pendekatan seperti ini memberikan pemahaman yang lebih kepada peserta didik dan menjadikan pembelajaran lebih bermakna (Umar, 2016).

Buku-buku yang digunakan di sekolah menjadi bagian dari observasi penelitian. Alangkah baiknya jika buku yang digunakan sekolah adalah satu jenis buku yang bersumber dari kementerian. Namun, jika menghendaki referensi bacaan tambahan bagi peserta didik, kementerian sebaiknya melakukan pengawasan lebih terhadap buku-buku lain yang beredar di sekolah. Hal ini menjadi penting karena banyak buku yang kaidah penulisannya berbeda dengan buku lainnya. Sebagai contoh, buku pelajaran fisika. Kaidah penulisan simbol atau keterangan persamaan yang berbeda membuat peserta didik menjadi bermakna ganda. Kaidah penulisan memiliki aturan khusus dengan arti dan makna yang berbeda-beda dalam fisika. Oleh karena itu, pemerintah perlu melakukan kajian lebih terhadap buku-buku yang dihasilkan penulis sehingga buku tersebut layak untuk digunakan sekolah-sekolah (Mukarromah \& Suparwoto, 2016). Kerja sama juga perlu dilakukan, seperti melakukan kegiatan Diskusi Kelompok Terpumpun (DKT) atau focus group discussion (FGD) agar 
mendapatkan konfirmasi judgment sehingga tidak terjadi penyimpangan terhadap konsep yang akan dipelajari peserta didik.

\section{Evaluasi Proses Kurikulum 2013}

Evaluasi proses diperoleh dari analisis terhadap proses pelaksanaan di lapangan. Adapun yang menjadi penilaian untuk proses adalah indikator pembuatan dan penyusunan RPP dan silabus. Uran (2018) menjelaskan bahwa sebanyak 93\% responden mengatakan sangat berhasil, 6\% responden mengatakan berhasil dan $1 \%$ responden mengatakan kurang berhasil. Kurang berhasil ini disebabkan semangat pendidik yang kurang dalam memperkaya bahan ajar. Secara umum, dalam menyelesaikan sebuah perangkat pembelajaran bagi pendidik tidak ada kendala.

Berdasarkan hasil wawancara dengan beberapa pendidik di sekolah, ditemukan sedikit keluhan dalam proses penyusunan perangkat pembelajaran. Perangkat pembelajaran pada K2013 terasa lebih rumit dibandingkan dengan Kurikulum Tingkat Satuan Pendidikan (KTSP). Hal ini disebabkan aspek yang harus dituangkan lebih rinci dan kompleks. Namun, dalam proses pembelajaran di kelas lebih mudah menjalankan K-2013 karena skenario yang tertuang dalam RPP sudah sangat jelas dan terperinci.

Pembuatan dan penggunaan metode dan media pembelajaran juga menjadi bahan evaluasi. Berdasarkan hasil wawancara diketahui bahwa metode pembelajaran sangat mudah diterapkan baik itu ceramah, demonstrasi, ataupun eksperimen. Kendala yang berarti dalam hal ini adalah pembuatan media yang rumit untuk beberapa mata pelajaran. Menurut Uran (2018) kekurangberhasilan K-2013 terdapat pada indikator kreativitas pendidik dalam penggunaan media pembelajaran. Untuk pembelajaran sains banyak media yang bisa diterapkan dalam pembelajaran. Selain media alat peraga, pendidik juga dapat menggunakan aplikasi yang berbasis teknologi. Sekarang banyak media-media laboratorium berbasis virtual yang dapat memberikan hasil yang baik pada proses pembelajaran peserta didik.

Kendala yang menjadi penghambat penggunaan media ini adalah sarana dan prasarana yang kurang mendukung belajar peserta didik. Namun, pendidik yang memiliki kompetensi yang baik tentu mampu menyikapi masalah ini dengan membuat media-media $3 D$ seperti alat peraga.

Pemberian motivasi dan evaluasi pembelajaran menjadi objek pengamatan. Berdasarkan hasil observasi diketahui bahwa masih banyak pendidik yang kurang memberikan motivasi kepada peserta didik dalam pembelajaran. Memberi motivasi kepada peserta didik untuk mengikuti proses K-2013 sangatlah penting. Motivasi merupakan kekuatan pendorong internal dan eksternal yang membuat individu dapat melakukan suatu kegiatan yang berorientasi pada pencapaian tujuan tertentu (Robescu \& Iancu, 2016). Motivasi yang dibangun pendidik dapat menyadarkan peserta didik bagaimana dampak yang diberikan K-2013 ke depannya. Kurangnya pemahaman peserta didik tentang tujuan dan manfaat dari penerapan K-2013 menghadirkan keluhan. Hal ini juga berdampak pada semangat belajar mereka yang berkurang.

Prinsip K-2013 yang mengacu pada pembelajaran berorientasi pada peserta didik atau student-centered membuat peserta didik banyak yang mengeluh. Peserta didik merasa tertekan dengan banyaknya perintah atau arahan dari pendidik kepada mereka. Mereka dituntut untuk mencari tahu sendiri informasi untuk kemudian dipahami dan dimaknai. Pendidik hanya menjadi fasilitator demi kelancaran investigasi yang mereka lakukan.

Pembelajaran seperti ini menjadi hal yang bermakna positif bagi pendidik tetapi berkesan negatif bagi siswa. Banyak pendapat yang menilai bahwa K-2013 memberatkan peserta didika karena selama pembelajaran berlangsung pusat kegiatan ada pada mereka. Bagi beberapa 
peserta didik yang memiliki pemahaman lebih tentang prinsip atau manfaat dari studentcentered pasti akan antusias mengikuti pembelajaran. Oleh karena itu, pendidik yang inovatif sangat diperlukan demi tercapainya tujuan kurikulum ini. Pendekatan PAIKEM (pembelajaran aktif, inovatif, kreatif, efektif, dan menyenangkan) dan model pembelajaran yang bervariasi menjadi salah satu solusi dalam melaksanakan pembelajaran yang baik. Pendekatan PAIKEM memberikan pengaruh yang baik pada hasil belajar peserta didik dibandingkan dengan pembelajaran tanpa pendekatan PAIKEM (Zahro, Muchtar, \& Misno, 2015).

Dalam proses penilaian pembelajaran di kelas, K-2013 lebih rumit karena aspek yang dinilai terlalu banyak. Pada akhirnya, pendidik melakukan strategi untuk memudahkannya dalam melakukan penilaian. Salah satu caranya adalah dengan menggunakan pola penyederhanaan pada batas atas dan batas bawah saja. Penilaian langsung dilakukan ke dalam pengelompokkan yang paling pintar dan paling tidak pintar atau yang paling baik dan paling tidak baik, dan yang lainnya dianggap umum atau tengah-tengah.

Cara ini dirasa lebih efektif mengingat waktu yang ada untuk melakukan penilaian terbatas. Komponen materi yang menuntut waktu lebih dalam memahami setiap ilmunya menjadi alasan utama strategi ini. Jurnal penilaian keseharian yang dipegang pendidik belum begitu mampu diterapkan maksimal. Pendidik benar-benar mengharapkan ada format penilaian yang memang sangat mudah dalam penilaian sehingga semua bentuk evaluasi diri pada peserta didik dapat maksimal diberikan.

\section{Evaluasi Produk Kurikulum 2013}

Evaluasi produk diperoleh dari analisis terhadap produk implementasi K-2013. Indikator produk yang dievaluasi adalah produk silabus dan rencana pelaksanaan pembelajaran (RPP) yang dihasilkan oleh pendidik serta prestasi peserta didik. Berdasarkan hasil pengamatan di sekolah, perangkat yang dihasilkan oleh pendidik sangat baik. Perangkat yang disusun detail dan lengkap untuk menunjang proses pembelajaran.

Keberhasilan pembuatan perangkat ini menimbulkan keluhan dari beberapa pendidik karena mereka merasa diberatkan. Proses penyusunan perangkat administrasi K-2013 lebih rumit daripada perangkat yang ada pada kurikulum sebelumnya. K-2013 memiliki lebih banyak halaman sehingga dalam proses penyusunanya memakan waktu yang cukup lama. Proses pencetakannya pun banyak menghabiskan kertas dan biaya.

Keputusan Menteri Pendidikan dan Kebudayaan yang meminta agar RPP disederhanakan (Kemdikbud, 2019) menjadi solusi yang diharapkan oleh pendidik. Pasal yang tertulis dalam RPP terkadang tidak sejalan dengan realita pelaksanaan. Keputusan mengenai kebebasan yang diberikan kepada sekolah untuk menyusun RPP sendiri dirasa sangat tepat. Berdasar pada prinsip efektif, efisien, dan berorientasi pada peserta didik, RPP yang dibuat dapat bersifat adaptif dan tepat sasaran.

Berdasarkan hasil tinjauan prestasi peserta didik, terdapat peningkatan prestasi yang dirasakan oleh sekolah. Prestasi akademik dan nonakademik dinilai semakin berkembang. Meningkatnya prestasi ini disebabkan pendidik yang mampu memposisikan fungsinya sebagai fasilitator yang baik. Peserta didik juga tidak memiliki keterbatasan dalam berfikir dan berkreativitas. Mereka bebas mengeksplor pengetahuan yang dimiliki tanpa ada rasa takut/ khawatir.

Banyaknya prestasi yang ditorehkan peserta didik menjadi bukti dampak dari keterlaksanaan $\mathrm{K}-2013$. Dunia internasional telah berbicara banyak tentang prestasi-prestasi yang dihasilkan peserta didik di Kota Mataram. Sebagai contoh misalnya pada bidang akademik, peserta didik asal Kota Mataram mampu 
mempersembahkan medali emas dan perak dalam ajang "The world Scholar's Cup" di Philiphina (MetroNTB, 2019). Sementara itu, dibidang non akademik atlet Indonesia yang juga berasal dari salah satu sekolah di Kota Mataram menjuarai Kejuaraan Atletik Asia 2019 dengan meraih medali perak (Raya, 2019).

\section{SIMPULAN DAN SARAN}

\section{Simpulan}

Penerapan K-2013 pada SMA di Kota Mataram cenderung terlaksana dengan baik. Indikator keterlaksanaan dapat terlihat dari beberapa komponen yang telah berjalan dan menemukan hasil yang baik. Namun, dalam pelaksanaanya mengalami sedikit kendala dan permasalahan. Beberapa permasalahan tersebut di antaranya 1) masih ada kebijakan sekolah yang kurang tepat terhadap peserta didik; 2) keterbatasan sarana dan prasarana sehingga kurang menunjang proses kegiatan pembelajaran; 3) kreativitas pendidik dalam mengelola pembelajaran yang masih kurang dan terkesan monoton; 4) penyusunan administrasi yang rumit dan terkesan memberatkan karena sangat detail dan padat. K-2013 masih dapat terus dilanjutkan karena sesuai dengan perkembangan era teknologi sehingga tidak menggerus pendidikan karakter yang ada pada peserta didik.

\section{Saran}

Berdasarkan hasil dan pembahasan di atas diberikan beberapa saran sebagai berikut. Pertama, melengkapi kompetensi pendidik dengan pemahaman terhadap aturan/kebijakan yang ada sehingga dapat mengontrol kebijakan pribadi sesuai aturan yang ada. Kedua, mempercepat pengadaan sarana dan prasarana sekolah dengan sebuah prioritas demi terlaksananya K-2013 dengan baik. Ketiga, menyikapi keterbatasan fasilitas yang ada, pendidik harus kreatif dalam melihat peluang ketersediaan teknologi lain yang mampu menunjang pembelajaran K-2013, seperti misalnya penggunaan android dalam pembelajaran yang telah banyak digunakan di beberapa tempat. Keempat, menyederhanakan perangkat pembelajaran penting untuk dilakukan sehingga pendidik tidak terlalu direpotkan oleh persiapan perangkat melainkan fokus pada implementasi sesuai harapan K-2013.

Fungsi kontrol (dinas terkait di tingkat daerah dan kementerian di pusat) dan fungsi pelaksana (sekolah) harus ditingkatkan serta dapat bekerja sama dengan baik. Jika setiap elemen bekerja sama dengan baik dan saling menguatkan satu sama lain, implementasi kurikulum lebih mudah dilaksanakan. Hasil yang ingin dicapai sesuai tujuan penerapan K-2013 juga lebih mudah terwujud. Hal lain apabila dilakukan penilaian (assesment) terhadap implementasi kurikulum setiap tahun secara serentak di tiap-tiap sekolah, tolok ukur kemajuan pendidikan tidak hanya dapat dilihat dari kelulusan peserta didik, melainkan kemampuan sekolah dalam mempersiapkan, melaksanakan, dan memperbaiki setiap komponen penunjang kurikulum.

\section{Ucapan Terima Kasih}

Ucapan terimakasih kepada narasumber yang telah memberikan pandangan sehingga menghasilkan beberapa masukan dan saran untuk membantu perbaikan Kurikulum 2013 pada artikel ini. Arahan, masukan, dan ilmu tentang evaluasi kurikulum sangat bermanfaat dan menginspirasi beberapa solusi untuk Kurikulum 2013. 


\section{PUSTAKA ACUAN}

Agustin, R.S. \& Puro, S. (2016). Strategy of curriculum development based on project-based learning (Case study: SMAN 1 Tanta Tanjung Tabalong South of Kalimantan). Prosiding ICTTE FKIP UNS 2015, 1(1).

Ahmad, S. (2014). Problematika Kurikulum 2013 dan kepemimpinan instruksional kepala sekolah. Jurnal Pencerahan, 8(2), 98-108. https://doi.org/10.13170/jp.8.2.2158.

Ary, D., Jacobs, L.C. \& Sorensen, C.K. (2010). Introduction to research in education. USA: Cengage Learning.

Gunawan, Harjono, A., Sahidu, H., \& Herayanti, L. (2017). Virtual laboratory to improve students' problem-solving skills on electricity concept. Jurnal Pendidikan IPA Indonesia, 6(2), 257-264. https://doi.org/10.15294/jpii.v6i2.9481.

Hamalik, O. (2012). Kurikulum dan pembelajaran. Jakarta: Bumi Aksara.

Husnaini, S.J. \& Chen, S. 2019. Effects of guided inquiry virtual and physical laboratories on conceptual understanding, inquiry performance, scientific inquiry self-efficacy, and enjoyment. Physical Review Physics Education Research. 15(1) https://doi.org/10.1103/ PhysRevPhysEducRes.15.010119.

Kurniaman, O. \& Noviana, E. (2017). Penerapan Kurikulum 2013 dalam meningkatkan keterampilan, sikap dan pengetahuan. Jurnal Primary, 6(2), 389-396.

Kementerian Pendidikan dan Kebudayaan. (2013). Peraturan Menteri Pendidikan dan Kebudayaan Republik Indonesia Nomor 65 Tahun 2013 tentang Standar Proses Pendidikan Dasar dan Menengah.

Kementerian Pendidikan dan Kebudayaan. (2019). Laporan Hasil Ujian Nasional. Jakarta: Puspendik.

Kementerian Pendidikan dan Kebudayaan. (2019). Surat Edaran Nomor 14 Tahun 2019 tentang Penyederhanaan Rencana Pelaksanaan Pembelajaran. Jakarta.

Mardapi, D. (2005). Penyusunan Tes Hasil Relajar. Yogyakarta: Program Pascasarjana. Universitas Negeri Yogyakarta.

Mastur. (2017). Implementasi Kurikulum 2013 dalam pelaksanaan pembelajaran di SMP. Jurnal Inovasi Teknologi Pendidikan. 4(1), 50-64. https://doi.org/10.21831/jitp.v4i1.10131.

MetroNTB. (2019). Tiga Siswa MAN 2 Mataram Raih Emas dan Perak Di The World Scholar's Philipina. MetroNTB. https://metrontb.com/28058/pendidikan/tiga-siswa-man-2-mataramraih-emas-dan-perak-di-the-world-scholars-philipina/, diakses tanggal 13 September 2019.

Moris, S.Z. \& Gibson, C.L. (2011). Corporal punishment's influence on children's aggressive and delinquent behavior. Criminal Justice and Behavior, 38, 818-839. https://doi.org/10.1177/ 0093854811406070.

Mukarromah, A. \& Suparwoto. (2016). Analisis bse dan non-bse Fisika SMA kelas X kriteria isi, organisasi, indeks serta glosarium. Jurnal Pendidikan Fisika, 5(7), 399-404.

Nugraheni, A.S. (2015). Controversy a policy change in the curriculum in indonesia in terms of the point of view of Indonesian language subject. Journal of Education and Practice, $6(2), 53-61$. 
Nur'aeni. (2017). Kekerasan orang tua pada anak. Jurnal Pendidikan Anak Usia Dini, 2(2), 97104.

Ozturk, I.H. (2011). Curriculum reform and teacher autonomy in Turkey: The case of the history teaching. International Journal of Instruction, 4(2), 113-128.

Raya, M. (2019). Lalu M Zohri Pecahkan Rekor Suryo Agung. Detiksport. https:// sport.detik.com/sport-lain/d-4520838/lalu-m-zohri-pecahkan-rekor-suryo-agung, diakses tanggal 23 April 2019.

Republik Indonesia. (2003). Undang-Undang Nomor 20 Tahun 2003 tentang Sistem Pendidikan Nasional. Jakarta: Lembaran Negara.

Republik Indonesia. (2014). Undang-Undang Nomor 35 Tahun 2014 tentang Perlindungan Anak. Jakarta: Lembaran Negara.

Retnaningsih, H. (2012). Masalah kurikulum baru tahun 2013. Info Singkat Kesejahteraan Sosial, IV (24), 9-12.

Rivalina, R. (2014). Kompetensi teknologi informasi dan komunikasi pendidik dalam peningkatan kualitas pembelajaran. Jurnal Teknodik, 18(2), 165-176.

Robescu, O. \& Iancu, A.G. (2016). The effects of motivation on employes performance in organizations. Valahian Journal of Economic Studies, 7(21), 49-56. https://doi.org/ 10.1515/vjes-2016-0006.

Setyawan, D. (2017). Berdasarkan rilis KPAI, 84 persen anak di Indonesia mengalami kekerasan di sekolah. KPAI. https://www.kpai.go.id/berita/berdasarkan-rilis-kpai-84-persen-anak-diindonesia-mengalami-kekerasan-di-sekolah, diakses 22 Februari 2017.

Setyosari, P. (2010). Metode penelitian pendidikan dan pengembangan. Jakarta: Kencana.

Umar, M.A. (2016). Penerapan pendekatan saintifik dengan menggunakan metode pembelajaran berbasis proyek (project-based learning) pada mata pelajaran Kimia. Jurnal Entropi, $11(2), 132-138$.

Uran, L.L. (2018). Evaluasi implementasi KTSP dan Kurikulum 2013 pada SMK se-Kabupaten Belu, Nusa Tenggara Timur. Jurnal Penelitian dan Evaluasi Pendidikan, 22(1), 1-11. https:// doi.org/10.21831/pep.v22i1.13309.

Yudhi, G. (2019). Semangat Melengkapi Fasilitas TI Sekolah: Apakah Dapat Memperbaiki Capaian UNBK? (Artikel Pendalaman Hasil Ujian Nasional). Jakarta: Puspendik.

Yuliana, L. (2019). Ketercapaian standar nasional pendidikan di sekolah menengah atas. Jurnal Pendidikan dan Kebudayaan. 4(2), 197-212. https://doi.org/10.24832/jpnk.v4i2.1457.

Zahro, N.F., Muchtar, I., \& Misno. (2015). Pengaruh penerapan pendekatan PAIKEM terhadap hasil belajar siswa kelas $V$ mata pelajaran PKn pokok bahasan keputusan bersama di SDN Yosorati 02 Jember Tahun Ajaran 2014/2015. Jurnal Pendidikan, 1(1), 1-5.

Zamhuri, A. (2019). Kualitas pendidikan, NTB ranking 33 dari 34 provinsi. Radar Lombok. https:/ /radarlombok.co.id/kualitas-pendidikan-ntb-ranking-33-dari-34-provinsi.html, diakses tanggal 25 Juli 2019. 